\title{
Investigating decadal changes in persistent organic pollutants in Scottish grey seal pups
}

\author{
Kelly J. Robinson ${ }^{1}$ (D) | Ailsa J. Hall ${ }^{1}$ (D) | Georges Scholl ${ }^{2}$ | Cathy Debier ${ }^{3}$ | \\ Jean-Pierre Thomé ${ }^{4}$ | Gauthier Eppe ${ }^{2}$ | Catherine Adam ${ }^{4}$ | Kimberley A. Bennett ${ }^{5}$
}

${ }^{1}$ Sea Mammal Research Unit, Scottish Oceans Institute, University of St Andrews, St Andrews, Fife, UK

${ }^{2}$ Department of Chemistry, Center for Analytical Research and Technology (CART), Université de Liège, Liège, Belgium

${ }^{3}$ Louvain Institute of Biomolecular Science and Technology, Université Catholique de Louvain, Leuven, Belgium

${ }^{4}$ Laboratory of Animal Ecology and Ecotoxicology (LEAE), Center for Analytical Research and Technology (CART), Université de Liège, Liège, Belgium

${ }^{5}$ Division of Science, School of Science Engineering and Technology, Abertay University, Dundee, UK

\section{Correspondence}

Kelly J. Robinson, Sea Mammal Research Unit, Scottish Oceans Institute, University of St Andrews, St Andrews, Fife, UK.

Email: kjr33@st-andrews.ac.uk

\section{Funding information}

Natural Environment Research Council (NERC), Grant/Award Numbers: NE/M01357X/1, NE/ M013723/1 and SMRU 1001

\section{Abstract}

1. Persistent organic pollutants (POPs) remain a risk to marine ecosystem health. POPs accumulate in fat tissue and are biomagnified up through food webs, generating high concentrations in apex predators, including marine mammals. Seals are thus often cited as sentinels of marine environment POP levels. Measuring changes across decadal timescales in these animals is key to understanding the effectiveness of regulations controlling POPs, predicting health, population, and ecosystem level impacts, and informing conservation and management strategies. Information on recent changes in legacy POPs in seals is relatively sparse, however, and datasets are not always continuous in the absence of dedicated POP monitoring programmes.

2. Here, POP concentrations in the blubber of weaned grey seal pups from the Isle of May, Scotland, were compared between studies investigating POP impacts on survival and energy balance in 2002, and in 2015-17. By 2017, the total dioxin-like polychlorinated biphenyls ( $\Sigma \mathrm{DL}-\mathrm{CBs}$ ) and the total non-dioxin-like polychlorinated biphenyls ( $\Sigma$ NDL-CBs) had decreased to $~ 75 \%$ of 2002 levels.

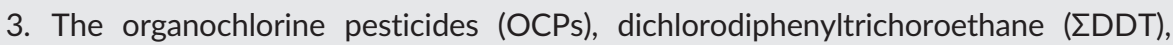
dichlorodiphenyldichloroethylene (DDE), and dichlorodiphenyldichoroethane (DDD), and some CB congeners, did not fall over the 15-year period; however, the power to detect small changes at low concentrations was limited.

4. High DDE and a lack of change in DDD are likely to reflect the low excretion of DDT metabolites, rather than recent exposure.

5. The limited change in many POPs over 15 years suggest that risks remain for energy balance, endocrine status, and immune function in grey seal pups, with contingent effects on conservation and management objectives for this species.

6. These data highlight the need for long-term datasets and parity in sampling and analytical methods to evaluate continuing impacts of POPs in grey seals and on marine ecosystems more widely.

\section{KEYWORDS}

coastal, mammals, ocean, physiology, pollution 


\section{1 | INTRODUCTION}

Persistent organic pollutants (POPs) are lipid-soluble, highly stable, toxic chemicals that have far-reaching negative impacts on aquatic ecosystems (Manzetti, Roos van der Spoel, \& van der Spoel, 2014; Sonne et al., 2017). The manufacture and release of legacy POPs into the environment has been tightly regulated or banned, starting with the polychlorinated biphenyls (CBs), in the late 1970s, and more recently the polybrominated diethyl ethers (BDEs), in the early 2000s (United Nations Environment Programme (UNEP), 2001), with more added to the Stockholm Convention list as their effects are realized. Despite these global regulations to control and reduce POP levels, their resistance to chemical, biological, and photolytic breakdown, and the potential for long-distance transfer, has resulted in high POP concentrations in biota, even in remote regions of the world such as isolated marine environments (Jamieson, Malkocs, Piertney, Fujii, \& Zhang, 2017). POPs can either be directly released into marine environments from poorly regulated or unidentified sources (GómezGutiérrez, Garnacho, Bayona, \& Albaigés, 2007) or are transported in the atmosphere and deposited into marine waters from distant regions of the world (Dachs et al., 2002; Jurado et al., 2004). POPs may also be released into marine environments or transferred to organisms via microplastic pollution (reviewed in Cole, Lindeque, Halsband, \& Galloway, 2011). Oceans thus act as key sinks for these chemicals and can be slow to respond to regulatory measures that have more immediate impacts in terrestrial environments. Therefore, despite bans on POP production and use, there are still potential routes for these chemicals to enter the marine environment, where they persist for decades. Monitoring POP concentrations is essential to understand their occurrence and fate in ecosystems, evaluate mitigation strategies, identify hot spots of contamination, and document negative impacts on marine wildlife (Arctic Monitoring and Assessment Programme (AMAP), 2018; Rigét et al., 2016, 2019; Tanabe, 2002).

In natural environments, POPs are readily bioaccumulated up through food chains to generate high concentrations in top predators (Johnson-Restrepo, Kannan, Rapaport, \& Rodan, 2005), such as marine mammals (Helle, Olsson, \& Jensen, 1976a; Ross, Ellis, Ikonomou, Barrett-Lennard, \& Addison, 2000). They have the potential to negatively impact marine wildlife, and remain a conservation concern for marine mammal species worldwide (AMAP, 2018; Desforges et al., 2018; Jepson \& Law, 2016; Law et al., 2012). POPs such as CBs, BDEs, and organochlorine pesticides (OCPs), including dichlorodiphenyltrichoroethane (DDT), have been linked to endocrine disruption (Noël et al., 2017; Routti et al., 2010; Tanabe, 2002; Villanger et al., 2011, 2013) and negative impacts on reproductive (Helle, Olsson, \& Jensen, 1976b; Hoydal et al., 2017; Murphy et al., 2010; Reijnders, 1986) and immune (Fisk et al., 2005, Hall et al., 2006, Hammond, Hall, \& Dyrynda, 2005, reviewed in Desforges et al., 2016; Penin et al., 2018) function in marine mammals. POPs have also recently been connected with lipid disruption in a range of phyla (Lee et al., 2016; Speranza et al., 2016; Yadetie et al., 2017), including marine mammals (Castelli, Rusten, Goksøyr, \& Routti, 2014;
Robinson et al., 2018; Tartu et al., 2017), because they alter pathways that enable individuals to accumulate or mobilize fat reserves appropriately. Viable immune and endocrine function, successful reproductive efforts, and the ability to use energy stores are all crucial to the fitness and survival of individuals in the wild. It has been proposed that marine wildlife populations with high POP burdens may be unable to reproduce or survive as a result of chronic POP effects (Helle et al., 1976b; Ross, 2006), potentially preventing population recovery in some declining species (AMAP, 2018; De Guise, Martineau, Béland, \& Fournier, 1995; Desforges et al., 2018; Jepson et al., 2016; Noël, Barrett-Lennard, Guinet, Dangerfield, \& Ross, 2009). POPs may negatively impact on juvenile survivorship (Hall, Thomas, \& McConnell, 2009), even in populations that are increasing or stable in size, such as UK grey seals, Halichoerus grypus (SMRU, 2017). Documenting the local and global trends of POP prevalence in the marine environment is therefore vital for giving context to the population dynamics of wildlife species that are at greatest risk from POP exposure.

Marine mammals are particularly vulnerable to the impacts of lipophilic POPs because of their reliance on substantial subcutaneous blubber for fuel (Oftedal, 1993; Reilly, 1991) and insulation (Rosen \& Renouf, 1997). Data on trends in marine mammal POP concentrations in the decades following their restriction are well represented in the literature (e.g. Roos, Bäcklin, Helander, Rigét, \& Eriksson, 2012). Data on temporal changes in POP levels in marine mammals since the 2010s are relatively scarce, however (AMAP, 2018; Houde et al., 2017; Law, 2014; Rigét et al., 2016, 2019). In this study, blubber POP levels measured in weaned grey seal pups from 15 years ago (2002) were compared with those measured in recent years (201517) in the same UK North Sea population. The recent changes in POP levels described are intended to facilitate the evaluation of mitigation strategies, understand conservation and management implications for this population, and provide POP profiles for comparison with future monitoring. These data will help to identify POP classes that remain a particular risk to grey seals, but are of wider ecosystem concern (Bossart, 2011)

\section{2 | METHODS}

There is no long-term monitoring programme for POPs in the UK North Sea grey seals; however, two separate studies were performed 15 years apart to investigate the impact of POPs on survivability (in 2002; Hall et al., 2009) and energy balance (2015-17; Robinson et al., 2018) in grey seal pups. As these two studies have considerable overlap in methodology and measurements, the data were used to investigate whether changes have occurred in blubber POP concentrations in grey seal pups in this region.

\section{1 | Study site}

Fieldwork was conducted on the Isle of May, Scotland $\left(56^{\circ} 11^{\prime} \mathrm{N}\right.$, $02^{\circ} 33^{\prime} \mathrm{W}$ ), under permit from Scottish Natural Heritage (SNH). 
Blubber samples were collected from weaned pups in November and December 2002 ( $n=60$; 31 female and 29 male; Hall et al., 2009), and again in 2015 ( $n=30$; 18 female and 12 male), 2016 ( $n=23 ; 7$ female and 16 male; Robinson et al., 2018), and 2017 ( $n=29 ; 14$ female and 15 male). All sample collection was performed by personal licence holders or designated competent personnel under UK Home Office licence 80/1552 in 2002 and licence 70/7806 in 2015-17. This work received ethical approval from Abertay University and the University of St Andrews Animal Welfare and Ethics Committee (AWEC), and was performed in compliance with the Animal (Scientific Procedures) Act (ASPA) 1986 and the EU directive on the protection of animals used for scientific purposes (2010/63/EU).

\section{2 | Study animals}

All study animals were wild grey seals, aged $\sim 3-4$ weeks, born on the Isle of May in the year of sampling. All had successfully weaned at a normal weight from their mothers and were in the 1-4 week postweaning land-based fast (Hall et al., 2009; Hall, McConnell, \& Barker, 2001; Reilly, 1991). Pups were observed daily prior to and after weaning. Weaning dates were obtained for all pups except for two sampled in 2002. The sex and mass of the individual were recorded at capture.

\section{3 | Sample collection and storage}

Biopsy sampling and storage were performed as described previously (Hall et al., 2009; Robinson et al., 2018). Briefly, prior to sampling, pups were given a mass-specific dose of intravenous Zoletil ${ }^{\mathrm{TM}}$ and subcutaneous injections of Lignol ${ }^{\mathrm{TM}}$ at biopsy sites. A full-depth, 6-mm biopsy core was then taken from the dorsolateral pelvic region (Bennett et al., 2015). The 6-mm biopsy was immediately wrapped in foil and frozen at $-20^{\circ} \mathrm{C}$ for transport back to the laboratory for POP concentration analysis.

\section{4 | Sample analysis}

Samples collected in 2002 were analysed by the Centre for Chemicals Management, Lancaster Environment Centre, Lancaster University, and samples collected in 2015-17 were analysed at the Centre for Analytical Research and Technology (CART) at the University of Liège, Belgium. CBs and BDEs were analysed at CART in the Department of Chemistry, whereas OCPs were analysed at CART in the Laboratory of Animal Ecology and Ecotoxicology (LEAE). All POP concentrations are reported as $\mathrm{ng} \mathrm{g}^{-1}$ lipid.

Samples collected in 2016 and 2017 were extracted and concentrations of the following POPs were measured: six non-dioxin-like CBs (NDL-CBs; CB 28, 58, 101, 138, 153, and 180), eight dioxin-like CBs (DL-CBs; CB 105, 114, 118, 123, 156, 157, 167, and 189), nine BDEs (BDE 28, 47, 66, 85, 99, 100, 153, 154, and 183), and four OCPs ( $\sum \mathrm{DDT}\left(o, p^{\prime}-\mathrm{DDT}\right.$ and $p, p^{\prime}$-DDT summed), and its metabolites, dichlorodiphenyldichloroethane ( $\left.p, p^{\prime}-\mathrm{DDD}\right)$, dichlorodiphenyldichloroethylene
(p,p'-DDE), and hexachlorobenzene (HCB)). Samples collected in 2015 were only analysed for the six NDL-CBs, nine BDEs, and four OCPs. Samples from 2002 were analysed for a larger range of congeners than the samples in 2015-17 (see Hall et al., 2009). Therefore, for the current study the number of congeners from the 2002 data included in the statistical analysis was restricted to match the congeners analysed in 2016-17, and data from 2015 were excluded from the analysis of DL-CBs.

Methodological details of the extraction and detection methods used to analyse the 2002 samples are given in Hall et al. (2009). Briefly, samples were extracted with dichloromethane using the Soxhlet extraction method. An aliquot was taken for gravimetric lipid determination. Samples were spiked with seven ${ }^{13} \mathrm{C}$-labelled $\mathrm{CBs}$ and ${ }^{13} \mathrm{C}$ BDE 209 before extraction. Samples were cleaned using silica gel treated with sulphuric acid and secondarily with gel permeation chromatography. Samples were analysed using a gas chromatography mass spectroscopy (GC-MS) system in selected ion monitoring (SIM) mode using an extracted ion chromatogram (EIC) source with two ion masses monitored for each chemical. OCPs were analysed in electron ionization (EI) mode and BDEs were analysed using GC quadrapole $\mathrm{MS}$ in negative chemical ionization $(\mathrm{NCl})$ mode.

For the 2015-17 samples, the analytical protocol was the same at its early stages for all POPs. Briefly, approximately $200 \mathrm{mg}$ (wet weight) of blubber underwent accelerated solvent extraction (ASE; Dionex 200; ThermoFisher Scientific, Waltham, MA) using a mixture of hexane:dichloromethane $(90: 10 ; \mathrm{V}: \mathrm{V})$ at $125^{\circ} \mathrm{C}$ and $1.30410^{7} \mathrm{~Pa}$. The fat content was determined gravimetrically after solvent evaporation with a TurboVap LV concentration Evaporator workstation (TurboVap ${ }^{\circledR L V}$; Zymark, Charlotte, NC). The fat was then redissolved in $40 \mathrm{~mL}$ of hexane and split into two equal fractions: one for $\mathrm{CB}$ and $\mathrm{BDE}$ determination; the other for OCP determination. For the $\mathrm{CB}$ and $\mathrm{BDE}$ fraction, known quantities of ${ }^{13} \mathrm{C}$-labelled homologues in a standard solution containing all of the targeted CBs and BDEs was added to each sample as an internal standard. The extract was then concentrated in $1 \mathrm{~mL}$ before being loaded for clean-up on a multilayer basic alumina and acid silica column. This system removes major matrix interference from the extracts and separates the OCPs and mono-ortho fraction from the dioxin-like compound fraction. The column was eluted with hexane, followed by a solvent exchange to nonane with $100 \mu \mathrm{L}$ as the final volume. Recovery standards $\left({ }^{13} \mathrm{C}_{12}\right.$ BDE 77, ${ }^{13} \mathrm{C}_{12}$ BDE 138, and ${ }^{13} \mathrm{C}_{12} \mathrm{CB}$ 80) were added into the vial prior to $\mathrm{GC}$ high-resolution MS (GC-HRMS) analysis. The analysis was performed with an Autospec Ultima High Res Mass Spectrometer (Waters, Milford, MA) coupled to an Agilent 6890 GC (Agilent, Santa Clara, CA). The injection was carried out in split-less mode and the mass spectrometry used $\mathrm{EI}$ (at $40 \mathrm{eV}$ ) in SIM mode. For quantification of the OCPs, $50 \mu \mathrm{L}$ of a hexanic solution (100 pg $\mu^{-1}$ ) of $\mathrm{CB} 112$ (Dr. Ehrenstorfer ${ }^{\circledR} \mathrm{GmbH}$, Augsburg, Germany) were added to the extract as a surrogate internal standard to evaluate the efficiency of recovery. The clean-up of these extracts was conducted using $\mathrm{H}_{2} \mathrm{SO}_{4} 98 \%$ and then Florisil solid-phase enrichment (Supelco; Envi-Florisil, Bellefonte, PA), as described in Damseaux et al. (2017). Nonane $(5 \mu \mathrm{L})$ was added to the purified 
extract as a keeper. Each extract was evaporated under a gentle stream of nitrogen until only the keeper remained in the vial. The final extract was reconstituted with $45 \mu \mathrm{L}$ of $n$-hexane and $500 \mu \mathrm{L}$ of Mirex (100 pg $\mathrm{LL}^{-1}$ in hexane) as the injection volume internal standard (Dr. Erhenstorfer ${ }^{\circledR} \mathrm{GmbH}$ ). Neither Mirex nor CB 112 were detected in the samples during pre-test analysis, allowing their use as standards. Trace CB 209 was found in samples, however, precluding its use as a standard. Finally, the extracts were analysed by highresolution GC (Trace 2000; ThermoQuest, Milan, Italy) equipped with $a^{63} \mathrm{Ni}$ electron capture detector (ECD) and on-column injector to prevent $p, p^{\prime}$-DDT from being degraded in split/splitless injectors (Muir \& Sverko, 2006). OCPs were analysed on a $60 \mathrm{~m} \times 0.25 \mathrm{~mm}(0.25 \mathrm{~mm}$ film) DB-5ms capillary column (J\&W Scientific, now Agilent). Other analytical parameters are described in Debier et al. (2003a). Quantification was performed using internal standards. A calibration curve (1.5-250 pg $\mathrm{LL}^{-1}$ ) was established for each compound of interest. Confirmation of the identity and concentrations of the compounds of interest were periodically performed by GC-HRMS (Trace GC Ultra and ITQ 1100; ThermoQuest). The transfer line temperature was kept at $290^{\circ} \mathrm{C}$ and the ion trap temperature was set at $250^{\circ} \mathrm{C}$. El was performed at $70 \mathrm{eV}$ and the ion trap was operating in MS/MS mode. The quality control (QC) was pork fat, free of the compounds of interest. The pork fat was spiked with $5 \mathrm{ng} \mathrm{g}^{-1}$ lipid weight (Iw) nominal concentrations of a mixture of the OCPs of interest, forming the QC. The OCP concentrations in each sample and in the QC were corrected for initial fat weight, and the recovery percentage of the surrogate CB 112. Recovery rates in QCs ranged between $96 \pm 10.3 \%$ and $113 \pm 12.5 \%$ according to the OCP, and the recovery rates of the CB 112 surrogate internal standard was always between 70 and $110 \%$, in good agreement with the requirements of the DirectorateGeneral for Health and Consumers (SANCO, 2014). The limit of detection (LOD) was $0.02 \mathrm{ng} \mathrm{g}^{-1} \mathrm{Iw}$. The measured limit of quantification (LOQ) determined with CB-spiked pork fat was $0.07 \mathrm{ng} \mathrm{g}^{-1} \mathrm{Iw}$.

\section{5 | Statistical analysis}

All statistical analyses were performed using R 3.4.1 (R Development Core Team, 2012). Marine mammal species typically show high individual variability in POP concentrations (Bjurlid, Dam, Hoydal, \& Hagberg, 2018; Pomeroy et al., 1996). The smaller sample sizes for the three recent sampling years (2015, $n=30 ; 2016, n=23 ; 2017, n=29)$ compared with $2002(n=60)$ may thus be more strongly affected by the presence of a few individuals with very low or high POP concentrations in their blubber tissue. All data from 2015, 2016, and 2017 were therefore combined to generate a sample size more comparable with that collected in 2002 for individual congeners ( $n=82$ for NDL-CBs and OCPs in 2015-17; $n=52$ for DL-CBs in 2016-17). In addition to individual congener analysis, POPs were also summed into $\Sigma \mathrm{NDL}$ CBs, $\Sigma D L-C B s, \Sigma B D E s$, and $\Sigma D D X s$ (DDT, DDD, and DDE). CB and DDX concentrations were analysed for differences between 2002 and 2015-17. Methodological differences in the standards used for spiking between the Lancaster University and the University of Liège laboratories for the detection of BDEs precluded statistical comparison between the 2002 and 2015-17 datasets for this class of POPs.

As the distribution of POP concentrations was positively skewed, a generalized linear model (GLM) with a gamma distribution and a log link function was used to investigate: (i) the relationship between POP concentrations and sex, mass, and days post-weaning (Debier et al., 2006; Louis et al., 2014; Louis, Covaci, Crocker, \& Debier, 2016), as potential confounding factors; and (ii) the relationship between POP concentrations and time of sampling (year group), taking into account the effect of the confounding factors if necessary. Model fits to the data were assessed using residual analysis, and outliers were identified from quantile-quantile plots (QQ plots) using Cook's distance.

A power analysis was performed using G*POWER (Faul, Erdfelder, Lang, \& Buchner, 2007) to determine the probability of detecting a change between 2002 and 2015-17 (or 2016-17 for DL-CBs), on the basis of the sample sizes used, and the observed means and standard deviations for all summed POP classes.

\section{3 | RESULTS}

\subsection{Summary of the POP concentrations detected in weaned grey seal pups}

The median concentrations and ranges of the summed and individual POPs detected in grey seal pup blubber tissue are presented in Table 1. The CB profiles detected in pups from the Isle of May were consistent between year groups for both the NDL-CBs and DL-CBs measured in both studies, with the following abundance pattern for the different congeners: NDL-CB, $153>138>180>101>$ $52>28$; and $\mathrm{DL}-\mathrm{CB}, 118>105=156>114=157>189,167>123$.

For the eight BDEs measured in all years, the profiles have remained consistent over time, despite the different methods used to measure them. BDE 47 was consistently the most abundant congener, and BDEs 66 and 183 were the lowest in abundance. BDE 99 was consistently one of the more abundant congeners. BDEs 153 and 154 have been of consistently low concentration. The profiles of OCP abundances followed the same pattern between year groups: $\mathrm{DDE}>\mathrm{DDT}>\mathrm{HCB}>\mathrm{DDD}$.

\subsection{Analysis of potentially confounding variables: pup mass and days post-weaning}

There was no relationship between pup mass and the blubber concentration of any of the POPs, nor was there any link between the sex of the pup and blubber POP concentrations, either as summed groups or on an individual congener basis (GLMs, all $P>0.05$ ). The fit of the models to the data was investigated by residual analysis. Six of the data points in both model groups (sex and mass) were identified as outliers, causing some skewness in the residuals. The removal of these data points resulted in residuals with normal distribution, but without any change to any of the results. Therefore, there was no need to include sex or mass as additional explanatory variables in the final model. There 
TABLE 1 Median (range) blubber concentrations of individual and summed persistent organic pollutants (POP) congeners, \% blubber lipid, and body mass at capture of weaned grey seal pups from the Isle of May in 2002, 2015, 2016, and 2017. All concentrations are in ng $\mathrm{g}^{-1}$ lipid

\begin{tabular}{|c|c|c|c|c|}
\hline & 2002 & 2015 & 2016 & 2017 \\
\hline \multicolumn{5}{|l|}{ NDL PCBs } \\
\hline 28 & $13.0(8.0-37.4)$ & $6.2(0.8-33.3)$ & $1.4(0.4-62.6)$ & $0.4(0.4-32.3)$ \\
\hline 101 & $25.6(17.0-199.0)$ & $28.7(4.1-76.8)$ & $36.4(20.1-193.8)$ & $19.1(10.6-150.4)$ \\
\hline 138 & $216.2(104.0-1842.0)$ & $142.9(50.7-319.8)$ & $155.4(91.8-309.4)$ & $128.1(66.8-526.9)$ \\
\hline 180 & $59.1(17.0-734.0)$ & $53.6(21.1-210.1)$ & $43.9(14.3-122.6)$ & $35.1(16.5-479.9)$ \\
\hline$\Sigma \mathrm{NDL}-\mathrm{PCB}$ & $635.1(316.0-5165.8)$ & $545.5(211.3-1275.50$ & $541.7(211.3-1275.5)$ & $412.9(219.9-2192.9)$ \\
\hline \multicolumn{5}{|l|}{ DL PCBs } \\
\hline 105 & $4.0(1.6-21.5)$ & NA & $3.8(0.9-38.3)$ & $3.4(1.7-21.9)$ \\
\hline 156 & $5.2(2.1-47.6)$ & & $3.2(1.7-9.4)$ & $3.9(1.9-20.9)$ \\
\hline 157 & $1.0(2.1-47.6)$ & & $0.8(0.5-2.2)$ & $1.1(0.5-5.5)$ \\
\hline 167 & $0.6(1.4-1.6)$ & & $0.2(0.1-2.3)$ & $0.1(0.01-0.9)$ \\
\hline 189 & $0.9(0.01-0.9)$ & & $0.6(0.2-1.9)$ & $0.5(0.2-4.0)$ \\
\hline$\Sigma \mathrm{DL}-\mathrm{PCBs}$ & $26.2(14.1-153.8)$ & & $19.8(9.6-151.2)$ & $19.3(9.0-100.8)$ \\
\hline \multicolumn{5}{|l|}{ PBDE } \\
\hline 28 & $9.4(6.0-23.3)$ & $0.2(0.1-0.5)$ & $0.2(0.1-1.2)$ & $0.1(0.1-0.4)$ \\
\hline 47 & $67.1(14.0-288.0)$ & $18.4(8.8-57.3)$ & $16.4(7.9-58.7)$ & $13.5(6.2-60.9)$ \\
\hline 183 & $2.8(1.8-7.2)$ & $0.0(0.0-43.4)$ & $0.0(0.0-0.2)$ & $0.005(0.005-0.1)$ \\
\hline$\Sigma \mathrm{PBDE}$ & $104.3(69.6-344.0)$ & $23.4(10.4-67.7)$ & $23.2(10.2-70.1)$ & $16.4(7.6-69.2)$ \\
\hline \multicolumn{5}{|l|}{ OCP } \\
\hline DDT & $72.5(22.0-450.3)$ & $21.1(8.2-50.9)$ & $21.9(16.6-35.7)$ & $16.6(4.4-89.8)$ \\
\hline DDD & $8.1(4.2-27.3)$ & $20.3(8.1-55.2)$ & $6.5(1.9-13.4)$ & $3.6(0-14.3)$ \\
\hline DDE & $140.0(10.4-1046.5)$ & $288.3(146.7-573.6)$ & $180.6(108.4-301.5)$ & $185.4(111.5-477.9)$ \\
\hline$\Sigma \mathrm{DDX}$ & $219.3(67-1524)$ & $331.3(170.7-666.6)$ & $209.6(128.4-345.7)$ & $206.9(126.3-582.1)$ \\
\hline $\mathrm{HCB}$ & $8.9(1.7-45.4)$ & $11.8(4.1-68.7)$ & $9.5(0.0-45.1)$ & $6.9(2.3-58.2)$ \\
\hline \% lipid & Data unavailable & $88.0(39.6-93.0)$ & $85.8(56.3-88.8)$ & $84.2(77.9-89.2)$ \\
\hline Body mass at capture $(\mathrm{kg})$ & $41.7(28.7-56.4)$ & $41.8(31.8-50.0)$ & $39.8(32.8-50.4)$ & $37.2(23.2-48.8)$ \\
\hline
\end{tabular}

was also no relationship between days post-weaning and the concentration of any of the POPs, again either as summed groups or by individual congener (once again, the removal of outliers confirmed that the results were robust; GLMs, all $P>0.05$ ). This allowed a simple model with time of sampling (i.e. year group) as the explanatory variable and POP concentration as the dependent variable to be fitted to the data.

\section{3 | Comparison of CBs between year groups}

Blubber from weaned grey seal pups from the Isle of May contained lower concentrations of $\Sigma$ NDL-CBs in 2015-17 than in 2002, by 25\% (Figure 1; Table 2). Typically, animals in 2002 had higher levels of all NDL-CB congeners than in 2015-17 (Figure 2; Table 2). CB 28 


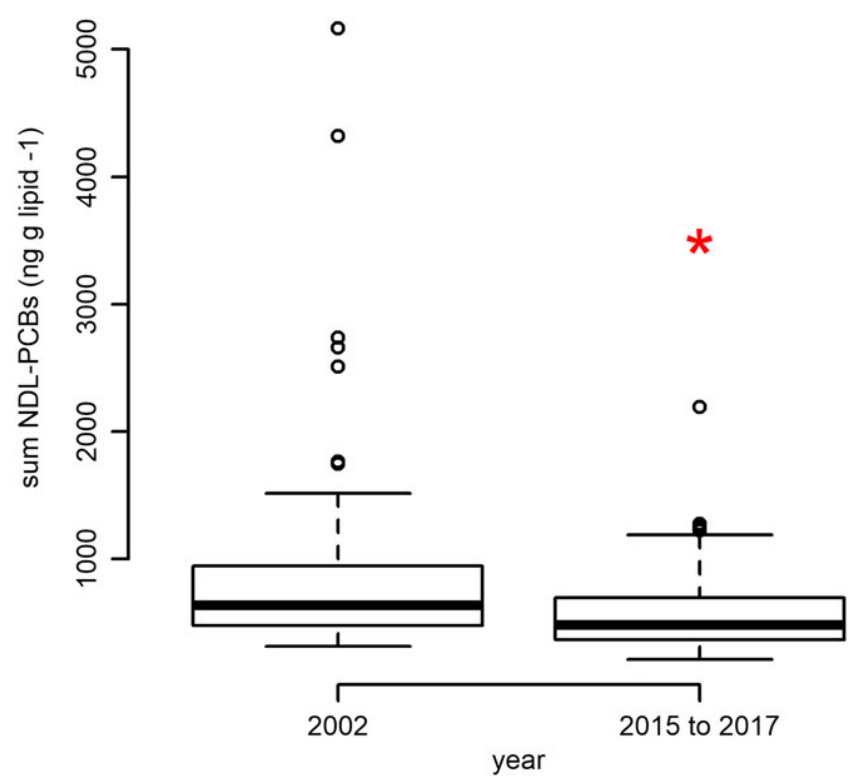

FIGURE 1 Median concentrations of summed non-dioxin-like polychlorinated biphenyls ( $\Sigma$ NDL-CBs) in blubber from weaned grey seal pups from $2002(n=60)$ and 2015-17 $(n=82)$ on the Isle of May, with upper and lower quartiles, $1.5 \times$ interquartile range and outliers The red asterisk indicates a significant reduction (generalized linear model, $P<0.05$ )

was nine-fold lower in 2015-17 than 2002. Smaller declines were apparent in the more abundant congeners: CB 138 was lower by 35\%, and CB 153 and CB 180 were lower by 20\%. CB 101 did not differ between years, and $C B 52$, one of the least abundant congeners, was $\sim 30 \%$ higher in the more recent samples (Figure 2; Table 2).

Concentrations of $\Sigma \mathrm{DL}-\mathrm{CBs}$ in blubber from the weaned grey seal pups were $\sim 25 \%$ higher in 2002 than in 2016-17 (Figure 3; Table 2). CB 114, 123, 156, 157, 167, and 189 were higher in 2002 compared with 2016 and 2017 (Figure 4; Table 2). The degree of reduction differed between congeners. In 2016-17, CB 189 was 50\% lower, CB 114 and CB 156 were $35 \%$ lower, and CB 157 was $20 \%$ lower than in 2002. The congeners with the lowest abundance, $C B 123$ and CB 167, were $98 \%$ and $75 \%$ lower in 2016-17, respectively. There was no significant decrease from 2002 to 2015-17 in two major DL-CBs: CB 105 and CB 118 (Tables 1 and 2).

\subsection{Comparison of OCPs between year groups}

There was no change in $\Sigma$ DDX concentrations between 2002 and 2015-17 in blubber from grey seal pups (Figure 5; Table 2); however, DDT was 70\% lower in 2015-17 than in 2002 (Figure 6; Table 2). In contrast, DDE increased by $\sim 46 \%$, and DDE as a proportion of DDX was 0.67 in 2002 but 0.88 in 2015-17. Neither DDD nor HCB changed over the same period (Figure 6; Table 2).

\section{5 | Power analysis}

The power to detect an effect size of 0.5 for $\Sigma$ NDL-CBs with the sample sizes used here was 0.876 . Similarly, for the total $\Sigma$ CBs $(n=60$
TABLE 2 Generalized linear model results with a gamma distribution and a log link function ( $F$ values from comparison with null, interceptonly model using analysis of variance (ANOVA) and model $P$ values) comparing blubber persistent organic pollutants (POP) concentrations from weaned grey seal pups in $2002(n=60)$ and 2015-17 (NDL-PCBs and OCPs; $n=82$, degrees of freedom $=140$ ) or 2016-17 (DL-PCB; $n=52$, degrees of freedom $=110$ ). Entries in bold indicate a significant difference $(P<0.05)$

\begin{tabular}{|c|c|c|}
\hline & $F$ & $P$ \\
\hline \multicolumn{3}{|l|}{ NDL PCBs } \\
\hline 28 & 22.8 & $<0.001$ \\
\hline 52 & 8.4 & 0.004 \\
\hline 101 & 0.02 & 0.894 \\
\hline 138 & 29.3 & $<0.001$ \\
\hline 153 & 11.9 & $<0.001$ \\
\hline 180 & 8.5 & 0.004 \\
\hline$\Sigma N D L-P C B$ & 14.7 & $<0.001$ \\
\hline \multicolumn{3}{|l|}{ DL PCBs } \\
\hline 105 & 0.50 & 0.482 \\
\hline 114 & 24.9 & $<0.001$ \\
\hline 118 & 0.67 & 0.404 \\
\hline 123 & 40.7 & $<0.001$ \\
\hline 156 & 13.4 & $<0.001$ \\
\hline 157 & 9.2 & 0.002 \\
\hline 167 & 28.1 & $<0.001$ \\
\hline 189 & 14.8 & $<0.001$ \\
\hline$\Sigma \mathrm{DL}-\mathrm{PCBs}$ & 4.3 & 0.040 \\
\hline \multicolumn{3}{|l|}{ OCP } \\
\hline DDT & 163.9 & $<0.001$ \\
\hline DDE & 5.1 & 0.020 \\
\hline DDD & 0.97 & 0.222 \\
\hline$\Sigma \mathrm{DDX}$ & 0.05 & 0.823 \\
\hline $\mathrm{HCB}$ & 2.0 & 0.160 \\
\hline
\end{tabular}

from 2002 and $n=52$ from 2016-17) the power to detect a medium effect (Cohen, 1988) of 0.5 was 0.956 . Where the concentrations were much lower, however, the power to detect an effect was reduced. For $\Sigma D L-C B s$, the power to detect the effect size of 0.26 seen here was only 0.27 . For $\Sigma D D X$ the effect size here was 0.36 , and the power to detect this size of change was 0.474 .

\section{4 | DISCUSSION}

\subsection{CB profiles and concentrations}

The abundance profile of CBs in blubber from post-weaned Isle of May grey seal pups did not change substantially between year groups. CB 153 was the most abundant congener, followed by CB 138, which is directly comparable with the most abundant congeners detected in previous studies on North Sea grey seals, both in blubber (Vanden 

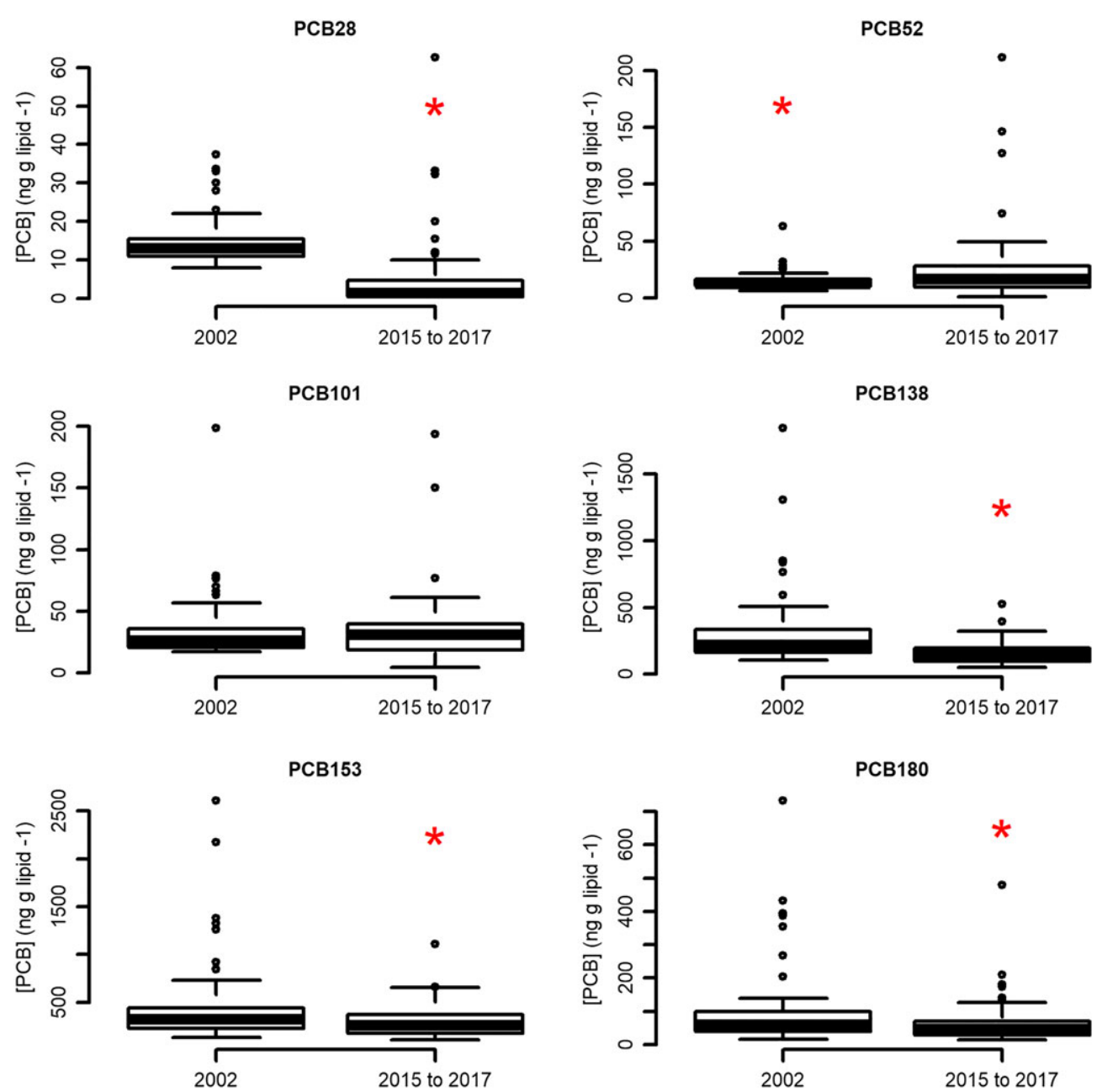

FIGURE 2 Median non-dioxin-like polychlorinated biphenyl (NDL-CB) concentrations for each congener measured in blubber from weaned pups in $2002(n=60)$ and 2015-17 ( $n=82)$ on the Isle of May, with upper and lower quartiles, 1.5x interquartile range, and outliers. Red asterisks indicate that levels were significantly lower (generalized linear model, $P<0.05$ ). Note the differences in $y$-axis ranges to allow the visualization of the data range for each congener

Berghe et al., 2012) and serum (Debier et al., 2003b; Vanden Berghe et al., 2012), and in phocid seals from other regions (Ross et al., 2013; Shaw, Brenner, Bourakovsky, Mahaffey, \& Perkins, 2005; Weijs et al., 2009). PCB concentrations here were approximately 10 -fold lower than those found in grey seal pups during the late 1990s to early 2000 s in heavily polluted regions, such as the Baltic Sea (Sørmo, Skaare, Jüssi, Jüssi, \& Jenssen, 2003), and 20-150-fold lower than found in juvenile and adult harbour seals from the North Sea in 2006-8 (Weijs et al., 2009). The median concentrations and ranges of NDL-CBs detected in this study in 2002 were comparable with those in grey seal pups in the Norwegian Sea and Gulf of St Lawrence (Sørmo et al., 2003), and in harbour seal pups during the late 1990s to early 2000s from the North Eastern Pacific (Ross et al., 2013). Data specifically documenting trends in DL-CBs in wild marine mammal species are limited (Law, 2014); however, one study reporting individual congener concentrations for four of the DL-CBs detected in this study (DL-CB 105, 118, 156, and 157) exists for grey seal pups in the late 1990s for the Baltic Sea and the East and West Atlantic (Sørmo et al., 2003), where concentrations were more than double those detected here. The summed CB concentrations from 2015 to 2017 here were comparable with those in juvenile and subadult ringed seals from Greenland and coastal USA and Canada sampled in 2009-11 (Brown et al., 2014; Rigét et al., 2016). Concentrations in adult ringed seals from 2009 to 2011 from the Labrador coast were between twoand four-fold higher (Brown et al., 2014). Ringed seals from the Baltic in 2015 had concentrations that were an order of magnitude higher for both NDL and DL-CBs than the concentrations reported here (Bjurlid, Roos, Eriscson-Jogsten, \& Hagberg, 2018).

\subsection{Differences in CB concentrations between year groups in Isle of May pups}

There was a modest $~ 25 \%$ reduction in both NDL- and DL-CBs in the blubber of North Sea grey seal pups from 2002 to 2015-17. Despite a large gap in the timing of the data collection, the power to detect this change in total CBs and NDL-CBs was high; however, except for 


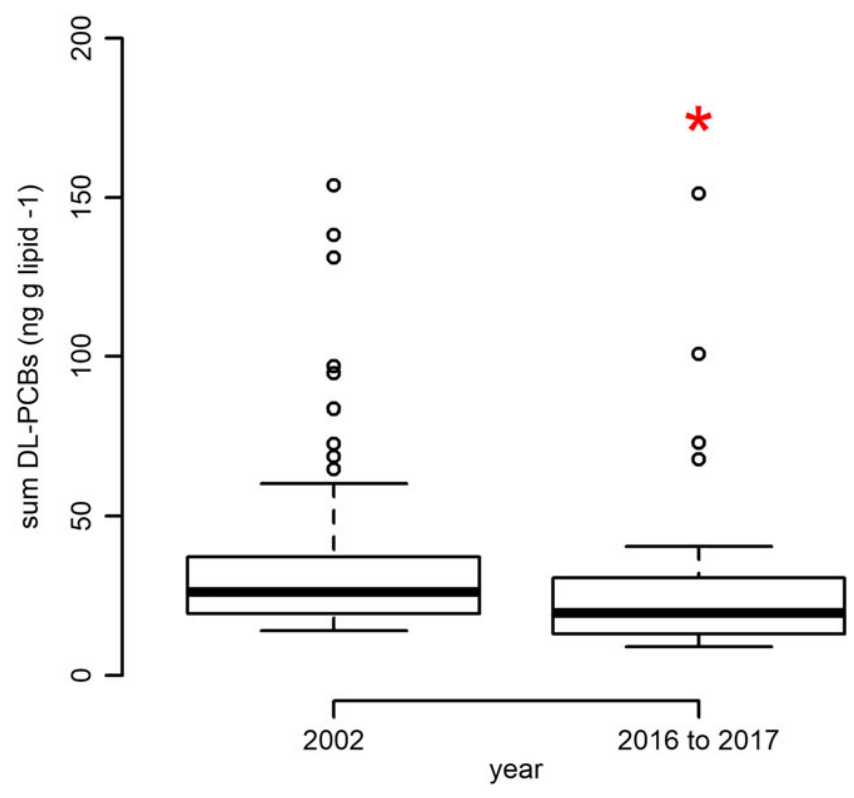

FIGURE 3 Median concentrations of summed dioxin-like polychlorinated biphenyls ( $\Sigma \mathrm{DL}-\mathrm{CBs}$ ) in blubber from weaned grey seal pups from $2002(n=60)$ and 2016-17 $(n=52)$ on the Isle of May, with upper and lower quartiles, $1.5 \times$ interquartile range, and outliers. The red asterisks indicates a significant reduction (generalized linear model, $P<0.05$ )

CB 52 and 101, the NDL-CB congeners analysed here showed at least a marginal decrease over the 15-year time period, which is consistent with several studies reporting that the declines in this group of chemicals found in the environment have slowed down after an initial rapid drop during the 1980s to early 1990s (Aguilar, Borrell, \& Reijnders, 2002; Bjurlid, Roos, et al., 2018; Jepson et al., 2016; Law et al., 2012; Law, 2014; Rigét, Vorkamp, Dietz, \& Rastogi, 2006; Rigét et al., 2016, 2019; Ross et al., 2013; Vorkamp, Rigét, Bossi, \& Dietz, 2011).

The most abundant DL congener (CB 118) did not significantly change between 2002 and 2015-17; however, for $\Sigma D L-C B s$ there was limited power to detect the effect size of 0.26 seen here, and the ability to detect changes in individual congeners is lower still, such that modest changes in CB 105 and 118 ( 9\% and 7\%, respectively) are not large enough to be reliable with the sample size in this study. The limited power to detect the observed change in DL-CBs results from their lower abundance, slow rate of change, and high degree of variation. This limited power is consistent with other studies showing that long-term monitoring over decades is required to identify time trends (AMAP, 2018; Rigét et al., 2016; Rigét et al., 2019). Indeed, only $12 \%$ of long-term studies have the ability to detect a $5 \%$ annual change in most POPs, and require more than 20 years of data to detect such a change (Rigét et al., 2019).

\section{3 | BDE profiles and concentrations}

The BDE profiles from 2015-17 are similar to those found in the same population of grey seals from the late 1990s and in 2008 (Kalantzi,
Hall, Thomas, \& Jones, 2005; Vanden Berghe et al., 2012), found in the blubber from grey seals elsewhere (Ikonomou \& Addison, 2008), and reported in recent studies on other marine mammals (Bjurlid, Dam, et al., 2018; Muir et al., 2006; Ochiai et al., 2017; Ramu, Kajiwara, Tanabe, Lam, \& Jefferson, 2005; Rigét et al., 2006; Ross et al., 2013; Weijs, Dirtu, et al., 2009). BDE 47 was always the most abundant congener, and accounted for $12.5-88.1 \%$ (median $80.9 \%$ ) of the BDEs detected.

The BDE levels reported here from weaned pups in 2002 were between two- and seven-fold lower than the values reported recently in maternal grey seal blubber in the UK from 2008 (Vanden Berghe et al., 2012) but were comparable with maternal blubber from populations in Canada in 1995 (Ikonomou \& Addison, 2008). Recent BDE values here are 10-20-fold lower than the levels reported in adult harbour seals from the North Sea from 1999 to 2004 (Weijs, Dirtu, et al., 2009), and are an order of magnitude lower than values reported in UK grey seal pup blubber from 1998 to 2000 (Kalantzi et al., 2005), and in Salish Sea harbour seal pup blubber from 1984 to 2009 (Ross et al., 2013). Findings from other studies in the marine environment globally suggest that BDE levels peaked in the early 2000s and then fell, as a result of the ban on penta- and tetra-mixes of BDEs (Airaksinen et al., 2014; Bjurlid, Dam, et al., 2018; Bjurlid, Roos, et al., 2018; Houde et al., 2017; Rigét et al., 2006, 2019; Ross et al., 2013; Sanganyado, Rajput, \& Liu, 2018; Shunthirasingham et al., 2018), and may have stabilized recently in some regions (Brown, MacDonald, Muir, \& Letcher, 2018; Fernandes et al., 2018; Houde et al., 2017; Rigét et al., 2016, 2019). In combination with the technical disparities discussed below, the BDE data here do not provide a sufficient recent time series to determine whether the bans have been effective at reducing BDEs in grey seal blubber, but provide a starting point for future studies or comparisons to investigate the efficacy of the ban and its impact on levels in top predators.

\section{4 | OCP profiles and concentrations}

The profiles of OCP abundances (i.e. DDE > DDT > DDD) matches previous results from phocid seals (Sørmo et al., 2003) and small cetaceans (Méndez-Fernandez et al., 2018). Concentrations of DDE were $\sim 20 \%$, and concentrations of DDT were $20-60 \%$, of those found in pups and juveniles from the same population in 19982000 (Kalantzi et al., 2005). They were 2.7-3.5-fold lower than the concentrations found in inner and outer blubber of Isle of May adult females during lactation in 2008 (Vanden Berghe et al., 2012). Concentrations were comparable with those detected in grey seal pups from the Gulf of St Lawrence and the Norwegian Sea in 1995, but approximately 16-fold lower than levels in pups from the Baltic (Sørmo et al., 2003). ¿DDX in all years of the current study were comparable with the concentrations detected in ringed seals from Greenland across 1999-2004 (Vorkamp, Rigét, Glasius, Muir, \& Dietz, 2008). HCB concentrations remained low across all years. 
PCB114

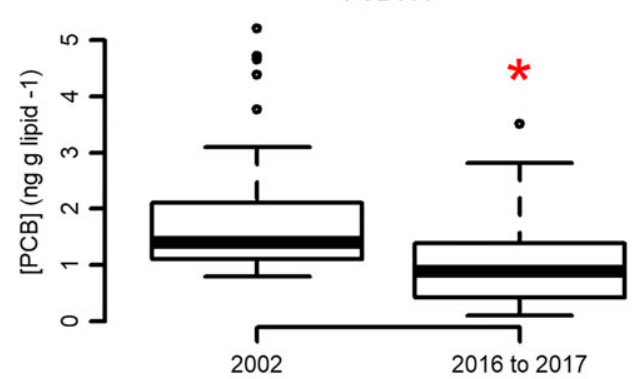

PCB156

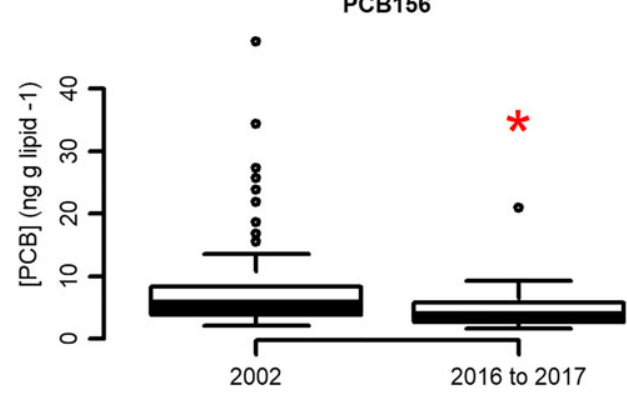

PCB167

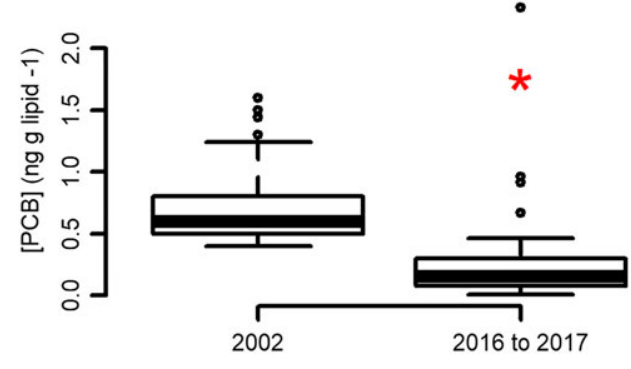

PCB123

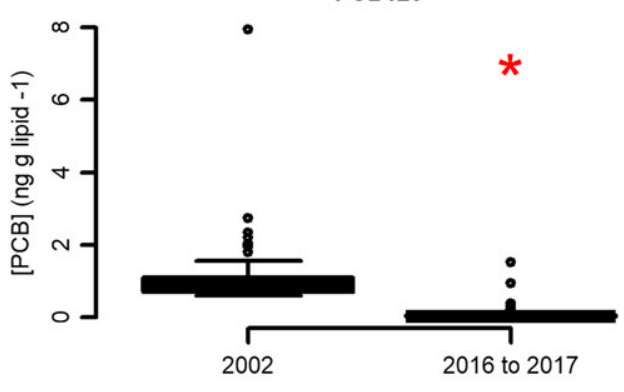

PCB157

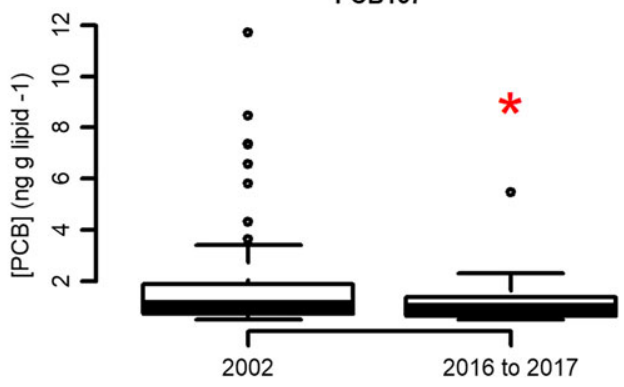

PCB189

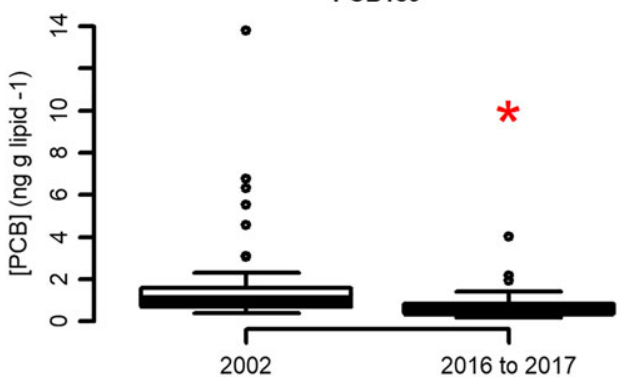

FIGURE 4 Median dioxin-like polychlorinated biphenyl (DL-CB) concentrations for each congener measured in blubber from weaned pups in $2002(n=60)$ and 2016-17 $(n=52)$ on the Isle of May, with upper and lower quartiles, $1.5 \times$ interquartile range, and outliers. Red asterisks indicate that levels were significantly lower (generalized linear model, $P<0.05$ ). Note the differences in $y$-axis ranges to allow the visualization of the data range for each congener

\section{5 | Differences in OCP concentrations between year groups in Isle of May pups}

The concentrations of DDT more than halved from 2002 to recent years of analysis. This difference was expected, because DDT is mainly converted to DDE or DDD over time, which are both more stable in organisms than the original compound (Ricking \& Schwarzbauer, 2012). Provided that no new sources of DDT enter an environment, the ratio of DDE:DDX in organisms should shift to greater than 0.6 (Aguilar, 1984). The ratios calculated here indicate that there have been no new sources of DDT in the North Sea since 2002. For our data, DDE:DDX ratios have shifted from a mean of $\sim 0.6$ in 2002 to means of $\sim 0.9$ in all recent years of analysis. Of the 60 seal pups sampled in 2002, 17 had ratios of <0.6, indicating that in 2002 there may have been a source of DDT where their mothers foraged.

Similar to the patterns of $C B$ decline in biota over the last decades, OCP concentrations initially fell steeply in the 1970s to 1990 s after their use was banned, but reductions have slowed or plateaued in a variety of marine top predator species since the 2000s (Roos et al., 2012). There are many studies reporting downward trends, or a lack of them, for DDX values in marine mammals before c. 2010 (Brown et al., 2018; Rigét et al., 2016). Significant declines of 8\% annually in DDX have been reported for ringed seals (Greenland 1986-2013, Rigét et al., 2016; Greenland 1994-2006, Vorkamp et al., 2008; Canadian Arctic 1998-2010; Brown et al., 2018), polar bears (Greenland 1984-2013; Rigét et al., 2016; Canadian Arctic 1989-2008; Brown et al., 2018), the harbour porpoise (UK 1992-2006; Law et al., 2012), and the spotted dolphin (four regions in the Atlantic 2005-15; Méndez-Fernandez et al., 2018), whereas studies showing no declining DDX trends exist for South American sea lions (Argentina 1991-2005; Borrell, Garcia-Solà, Aguilar, García, \& Crespo, 2010), striped dolphins (Japan 1978-2003; Isobe et al., 2009), and harbour seals (North-western Atlantic 1991-2001; Shaw et al., 2005). The current results also show a drop in DDT, an increase in DDE, and no change in DDD and HCB between 2002 and 2015-17. This is typical of time trends in these chemicals in a range of biota 


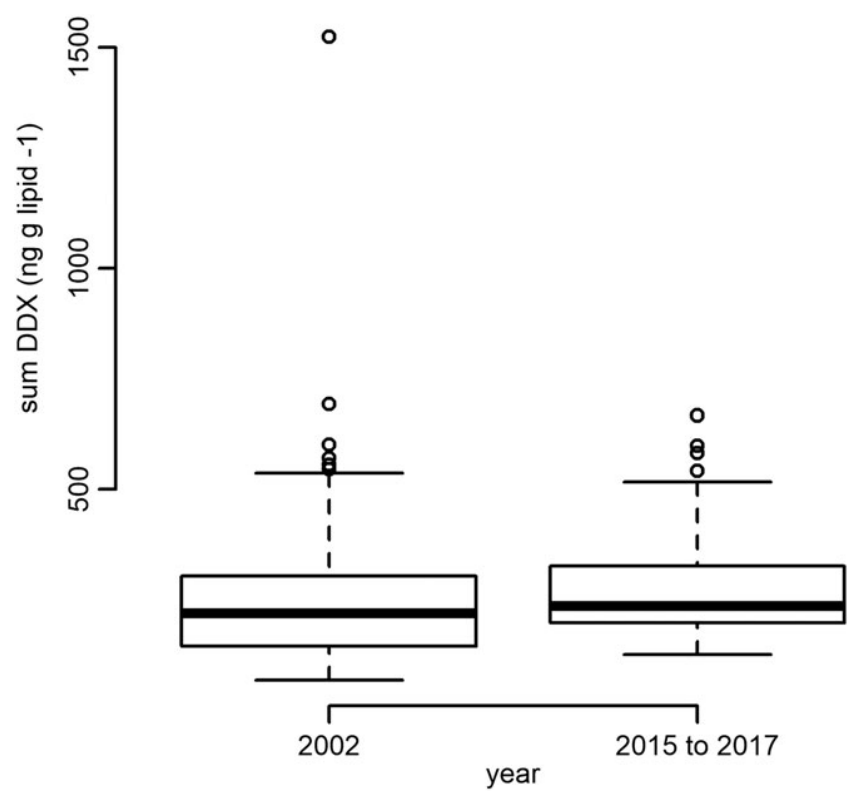

FIGURE 5 Median $\Sigma$ DDX (DDT, DDD, and DDE) concentrations in blubber from weaned grey seal pups from $2002(n=60)$ and 2015$17(n=82)$ on the Isle of May, with upper and lower quartiles, 1.5× interquartile range, and outliers

from the Artic, which generally show falling DDT, but no change in DDD and DDE in marine mammals (Rigét et al., 2019). The limited power to detect differences in $\mathrm{DDDX}$ here is in line with recent work showing similar difficulties, even in long-term monitoring programmes (Rigét et al., 2019).

\section{6 | Methodological and technical considerations}

The dependence of variability expressed as relative standard deviation on concentration is typical of the Horwitz trend that is a well-recognized phenomenon in POP analysis, and variability in POP measurements between labs is also typical from samples of high fat content (De Boer \& Wells, 2006), such as blubber. As samples from 2002 were not available for reanalysis, and the ability to replicate the 2002 method using recent samples was not an option, an interlaboratory comparison was not possible. However, the extraction, clean-up, and detection methods used in each case are accepted and equivalent approaches for PCB and OCP analysis (Covaci, Voorspoels, Ramos, Neels, \& Blust, 2007; Muir \& Sverko, 2006; Van Leeuwen, van Bavel, \& de Boer, 2013; Wang et al., 2010).

The standards used to measure BDEs s in 2002 and in more recent years differed. This is probably the most significant parameter that could explain the discrepancies observed for BDEs and is the reason that there is no direct statistical comparison. Although the apparent four-fold reduction in BDEs since 2002 seen here is consistent with recent downward trends from the early 2000s, a direct comparison cannot be made with the more recent data because the samples from 2002 were analysed using only ${ }^{13}$ C BDE 209 as the internal standard (Hall et al., 2009), rather than using standards for each congener. As
BDE 209 can degrade during high-temperature separation in the GC column to lower brominated congeners (Stapleton, 2006), the older method that used ${ }^{13} \mathrm{C}$ BDE 209 as a standard for detection may contain some inaccuracies in the levels measured, which could overestimate the between-year differences. In conjunction with the high degree of variability in the measurement of low-abundance congeners in recent samples, although the data are suggestive of a decline, it is difficult to conclude that a real reduction in BDEs has occurred in this population.

Using the same laboratory methods decades apart can be challenging in the face of the necessary continued efforts to refine analytical methods and improve the reproducibility between labs (Abalos et al., 2013; Covaci et al., 2007; De Boer \& Wells, 2006). The discrepancies in sampling and analysis that prevent direct comparison here highlight one difficulty in comparing historical data with contemporary data, and in obtaining comparable results for long-term data analysis. This argues for the need for standardization in sampling protocols, where possible, and the banking of tissue samples using appropriate storage to allow historical and contemporary samples to be analysed at the same time (Rigét et al., 2016, 2019).

\section{7 | Conservation and management implications}

UK grey seal numbers are currently stable or increasing throughout their monitored range (SMRU, 2017), suggesting that their population status is not under threat; however, POPs are important influencers of first-year survival in grey seal pups, which is a key component of the population dynamics of the species (Hall et al., 2009). The mechanism linking POPs with survival is unknown and may be multifaceted, including endocrine disruption and reduced immunocompetence. Although the POP concentrations found in the North Sea grey seal pups of this study are all well below the estimated toxic threshold values (Kannan, Blankenship, Jones, \& Giesy, 2000), summed concentrations of DL-CB and DDX have been linked to altered glucose uptake, lactate production, and lipolytic rates in the blubber tissue of the same pups that provided the 2016 data for this study (Robinson et al., 2018). Even apparently low concentrations of these chemicals may thus have significant physiological impacts, with potential health and energetic consequences early in life. In addition, POP effects are not additive and the cocktail present in the animal may produce effects at levels below the accepted thresholds for individual congeners or POP classes. Although the concentrations of CB 118 in the blubber of grey seals showing immunosuppression was higher (1998, $n=17$, median $98 \mathrm{ng} \mathrm{g}^{-1}$ lipid, range 52-211 ng g ${ }^{-1}$ lipid; Sørmo, Larsen, Johansen, Skaare, \& Jenssen, 2009) than the levels detected here (combined data 2016-17, $n=52$, median $10.2 \mathrm{ng} \mathrm{g}^{-1}$ lipid, range 3.7-92.9 $\mathrm{ng} \mathrm{g}^{-1}$ lipid), the two ranges do overlap. The lack of significant changes in the most abundant DL-CB, CB 118, and in DDX in the blubber of grey seal pups thus have potential conservation implications. Continued reductions in POPs would thus likely have beneficial effects on first-year survival probability for grey seal pups, with potential contingent effects on population structure and dynamics. 
DDT

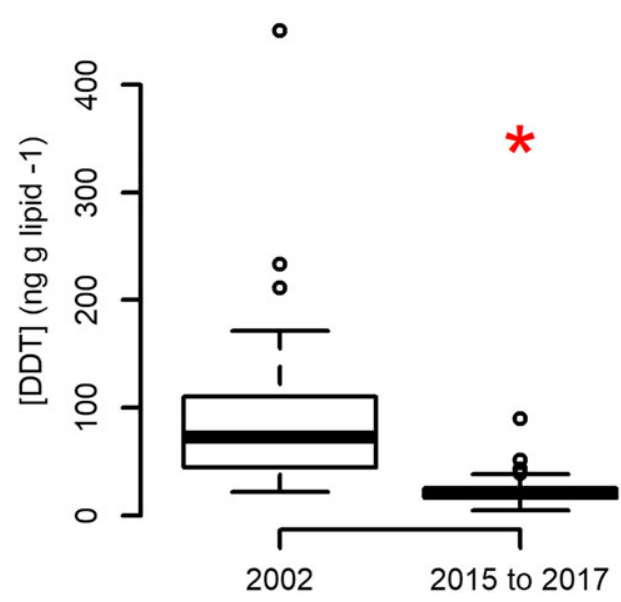

DDD

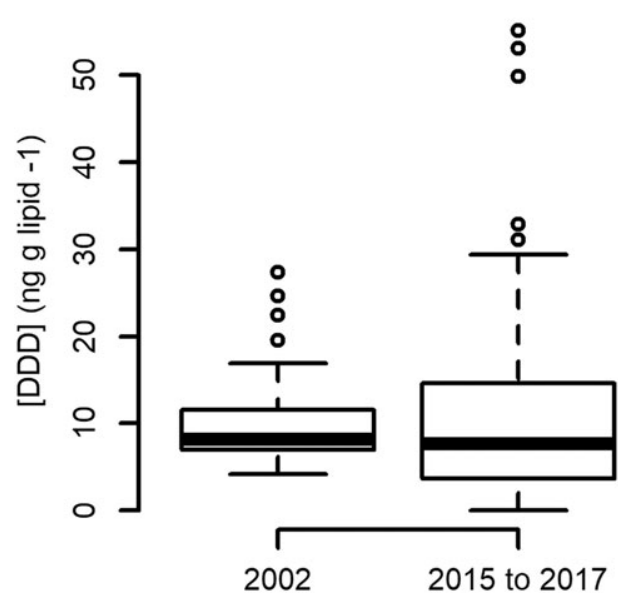

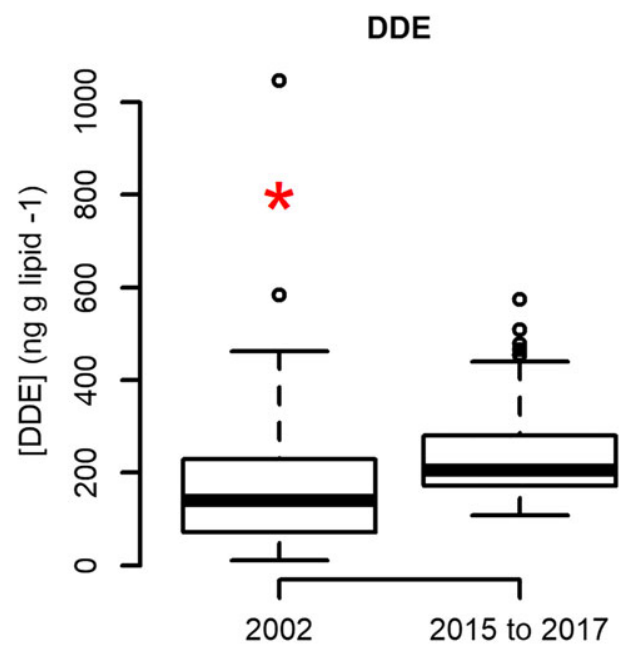

HCB

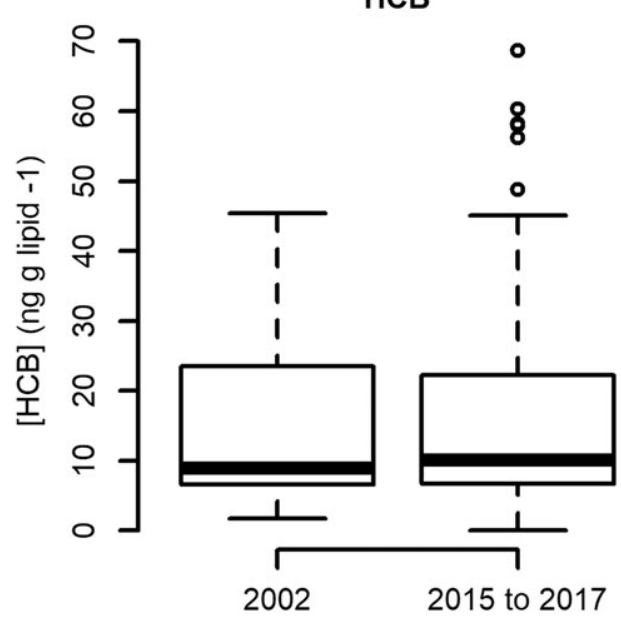

FIGURE 6 Median organochlorine pesticide (OCP) concentrations in blubber from weaned grey seal pups from 2002 ( $n=60$ ) and $2015-17$ ( $n=82$ ) on the Isle of May, with upper and lower quartiles, $1.5 \times$ interquartile range, and outliers. Red asterisks indicate that levels were significantly lower (generalized linear model, $P<0.05$ ). Note the differences in $y$-axis ranges to allow the visualization of the data range for each OCP

\section{5 | CONCLUSIONS}

Despite decades of regulations restricting the use of POPs globally, these persistent, toxic chemicals are still present in marine ecosystems and organisms. After substantial initial drops in the 1970s to 1990 s, declines have slowed or stalled in many regions. The findings from grey seal pups in the North Sea here concur with this global pattern and provide some of the most recent data for POP concentrations in these top marine predators. In the absence of long-term monitoring, we have shown that comparisons can be made between POP measurements from discrete studies many years apart, particularly for $\mathrm{CBs}$, but attention should also be paid to methodological differences, which may make spatial and temporal comparisons difficult. The current study highlights that a lack of time series data can make the interpretation of spot measures challenging, and emphasizes the need for continued, standardized monitoring of POP concentrations. Larger sample sizes and longer time series are needed to reliably detect changes in low-abundance summed POPs and individual congeners.
Such work will allow for the better prediction of population impacts, particularly when animals face multiple threats, which will improve the conservation efforts directed at grey seals and other species.

Although the POP concentrations detected in this study are below the values that cause severe toxic effects, even these 'low' concentrations are enough to cause endocrine disruption and alter physiological pathways, with unknown consequences for individual health and survival. The fact that low levels of POPs decrease the probability of survival and that levels are slow to decline should be taken into consideration in the development of conservation and management plans, because these compounds may continue to affect population structure as well as dynamics into the future.

\section{ACKNOWLEDGEMENTS}

We would like to thank Simon Moss, Holly Armstrong, and everyone who assisted with colony observations and sample collection on the Isle of May. We would like to thank Scottish Natural Heritage for 
the permit to work on the Isle of May, and the skipper and crew of the Osprey and May Princess for help with gear and personnel transport. We would also like to thank all of the staff at the University of Liège who provided training and assistance while KJR was in the lab processing samples for POP detection, and the staff at the Centre for Chemicals Management, Lancaster Environment Centre, Lancaster University, who performed the 2002 analysis. We would like to thank the two anonymous reviewers for their input on this article. The long-term programme of research on grey seals at the Isle of May was funded by the Natural Environment Research Council (NERC) national capability grant awarded to SMRU (SMRU 1001). KAB was funded by NERC grant NE/M013723/1 and AJH and KJR were funded by NE/M01357X/1 during the work. The funding bodies had no role in the design of the study, the collection of samples, the analysis of samples or data and the interpretation of the data.

\section{CONFLICT OF INTEREST}

The authors have no conflicts of interest to report.

\section{FUNDING INFORMATION}

Sea Mammal Research Unit (SMRU) Natural Environment Research Council (NERC) national capability grant SMRU 1001; NERC grants NE/M013723/1 and NE/M01357X/1.

\section{ORCID}

Kelly J. Robinson (10) https://orcid.org/0000-0002-6212-9710

Ailsa J. Hall (ID https://orcid.org/0000-0002-7562-1771

Kimberley A. Bennett (D) https://orcid.org/0000-0003-2168-6112

\section{REFERENCES}

Abalos, M., Abad, E., van Leeuwen, S. P. J., Lindström, G., Fiedler, H., de Boer, J., \& van Bavel, B. (2013). Results for PCDD/PCDF and dl-CBs in the First Round of UNEPs Biennial Global Interlaboratory Assessment on Persistent Organic Pollutants. Trends in Analytical Chemistry, 46, 98-109. https://doi.org/10.1016/j.trac.2012.11.003

Aguilar, A. (1984). Relationship of DDE/ $D D D T$ in marine mammals to the chronology of DDT input into the ecosystem. Canadian Journal of Fisheries and Aquatic Sciences, 41, 840-844. https://doi.org/10.1139/ f84-100

Aguilar, A., Borrell, A., \& Reijnders, P. J. H. (2002). Geographical and temporal variation in levels of organochlorine contaminants in marine mammals. Marine Environmental Research, 53, 425-452. https://doi. org/10.1016/S0141-1136(01)00128-3

Airaksinen, R., Hallikainen, A., Rantakokko, P., Ruokojärvi, P., Vuorinen, P. J., Parmanne, R., ... Kiviranta, H. (2014). Time trends and congener profiles of PCDD/Fs, CBs, and BDEs in Baltic herring off the coast of Finland during 1978-2009. Chemosphere, 114, 165-171. https://doi. org/10.1016/j.chemosphere.2014.03.097

Arctic Monitoring and Assessment Programme (AMAP). (2018). AMAP assessment 2018: biological effects of contaminants on Arctic wildlife and fish (p. 84). Tromsø, Norwayvii+: Arctic Monitoring and Assessment Programme (AMAP).

Bennett, K. A., Hughes, J., Stamatas, S., Brand, S., Foster, N. L., Moss, S. E. W., ... Pomeroy, P. P. (2015). Adiponectin and insulin in gray seals during suckling and fasting: Relationship with nutritional state and body mass during nursing in mothers and pups. Physiological and Biochemical Zoology, 88, 295-310. https://doi.org/10.1086/680862

Bjurlid, F., Dam, M., Hoydal, K., \& Hagberg, J. (2018). Occurrence of polybrominated dibenzo-p-dioxins, dibenzofurans (PBDD/Fs) and polybrominated diphenyl ethers (BDEs) in pilot whales (Globicephala melas) caught around the Faroe Islands. Chemosphere, 195, 11-20. https://doi.org/10.1016/j.chemosphere.2017.12.044

Bjurlid, F., Roos, A., Eriscson-Jogsten, I., \& Hagberg, J. (2018). Temporal trends of $\mathrm{PBDD} / \mathrm{Fs}, \mathrm{PCDD} / \mathrm{Fs}$, BDEs and $\mathrm{CBs}$ in ringed seals from the Baltic Sea (Pusa hispida botnica) between 1974 and 2015. Science of the Total Environment, 616-617, 1374-1383. https://doi.org/ 10.1016/j.scitotenv.2017.10.178

Borrell, A., Garcia-Solà, A., Aguilar, A., García, N. A., \& Crespo, E. A. (2010). Organochlorine residues in South American sea lions, Otaria flavescens (Shaw, 1800): Bioaccumulation and time trends. Bulletin of Environmental Contamination and Toxicology, 84, 731-737. https://doi.org/ 10.1007/s00128-010-0025-x

Bossart, G. D. (2011). Marine mammals as sentinel species for oceans and human health. Veterinary Pathology, 48, 676-690. https://doi.org/ 10.1177/0300985810388525

Brown, T. M., MacDonald, R. W., Muir, D. C. G., \& Letcher, R. J. (2018). The distribution and trends of persistent organic pollutants and mercury in marine mammals from Canada's Eastern Arctic. The Science of the Total Environment, 618, 500-517. https://doi.org/10.1016/j.scitotenv.2017. 11.052

Brown, T. M., Ross, P. S., Reimer, K. J., Veldhoen, N., Dangerfield, N. J., Fisk, A. T., \& Helbing, C. C. (2014). CB related effects thresholds as derived through gene transcript profiles in locally contaminated ringed seals (Pusa hispida). Environmental Science \& Technology, 48, 12952-12961. https://doi.org/10.1021/es5032294

Castelli, M. G., Rusten, M., Goksøyr, A., \& Routti, H. (2014). mRNA expression of genes regulating lipid metabolism in ringed seals (Pusa hispida) from differently polluted areas. Aquatic Toxicology, 146, 239-246. https://doi.org/10.1016/j.aquatox.2013.11.015

Cohen, J. (1988). Statistical power analysis for the behavioral sciences (2nd ed.). Hillsdale, N.J: Lawrence Erlbaum.

Cole, M., Lindeque, P., Halsband, C., \& Galloway, T. S. (2011). Microplastics as contaminants in the marine environment: A review. Marine Pollution Bulletin, 62, 2588-2597. https://doi.org/10.1016/j.marpolbul.2011. 09.025

Covaci, A., Voorspoels, S., Ramos, L., Neels, H., \& Blust, R. (2007). Recent developments in the analysis of brominated flame retardants and brominated natural compounds. Journal of Chromatography a, 1153, 145-171. https://doi.org/10.1016/j.chroma.2006.11.060

Dachs, J., Lohmann, R., Ockenden, W. A., Méjanelle, L., Eisenreich, S. J., \& Jones, K. C. (2002). Oceanic biogeochemical controls on global dynamics of persistent organic pollutants. Environmental Science \& Technology, 36, 4229-4237. https://doi.org/10.1021/es025724k

Damseaux, F., Kiszka, J. J., Heithaus, M. R., Scholl, G., Eppe, G., Thomé, J. P., ... Das, K. (2017). Spatial variation in the accumulation of POPs and mercury in bottlenose dolphins of the Lower Florida Keys and the coastal Everglades (South Florida). Environmental Pollution, 220, 577-587. https://doi.org/10.1016/j.envpol.2016.10.005

De Boer, J., \& Wells, D. E. (2006). Pitfalls in the analysis of brominated flame retardants in environmental, human and food samples - including results of three international interlaboratory studies. Trends in Analytical Chemistry, 25, 364-372. https://doi.org/10.1016/j.trac.2006.01.008

De Guise, S., Martineau, D., Béland, P., \& Fournier, M. (1995). Possible mechanisms of action of environmental contaminants on St. Lawrence beluga whales (Delphinapterus leucas). Environmental Health Perspectives, 103, 73-77. https://doi.org/10.1289/ehp.95103s473 
Debier, C., Chalon, C., Le Bœuf, B. J., de Tillesse, T., Larondelle, Y., \& Thomé, J. P. (2006). Mobilization of CBs from blubber to blood in northern elephant seals (Mirounga angustirostris) during the post-weaning fast. Aquatic Toxicology, 80, 149-157. https://doi.org/10.1016/j.aquatox. 2006.08.002

Debier, C., Pomeroy, P. P., Dupont, C., Joiris, C., Comblin, V., Le Boulengé, E., ... Thomé, J. P. (2003a). Quantitative dynamics of CB transfer from mother to pup during lactation in UK grey seals Halichoerus grypus. Marine Ecology Progress Series, 247, 237-248. https://doi.org/ 10.3354/meps247237

Debier, C., Pomeroy, P. P., Dupont, C., Joiris, C., Comblin, V., Le Boulengé, E., ... Thomé, J. P. (2003b). Dynamics of CB transfer from mother to pup during lactation in UK grey seals Halichoerus grypus: Differences in $\mathrm{CB}$ profile between compartments of transfer and changes during the lactation period. Marine Ecology Progress Series, 247, 249-256. https://doi.org/10.3354/meps247249

Desforges, J. P. W., Hall, A. J., McConnell, B. J., Rosing-Asvid, A., Barber, J. L., Brownlow, A., ... Dietz, R. (2018). Predicting global killer whale population collapse from CB pollution. Science, 361, 1373-1376. https://doi. org/10.1126/science.aat1953

Desforges, J. P. W., Sonne, C., Levin, M., Siebert, U., De Guise, S., \& Dietz, R. (2016). Immunotoxic effects of environmental pollutants in marine mammals. Environment International, 86, 126-139. https://doi.org/ 10.1016/j.envint.2015.10.007

Faul, F., Erdfelder, E., Lang, A.-G., \& Buchner, A. (2007). G*Power3: A flexible statistical power analysis program for the social, behavioural and biomedical sciences. Behavior Research Methods, 39, 175-191. https://doi.org/10.3758/BF03193146

Fernandes, A. R., Mortimer, D., Holmes, M., Rose, M., Zhihua, L., Huang, X., ... Marshall, L. (2018). Occurrence and spatial distribution of chemical contaminants in edible fish species collected from UK and proximate marine waters. Environment International, 114, 219-230. https://doi. org/10.1016/j.envint.2018.02.047

Fisk, A. T., De Wit, C. A., Wayland, M., Kuzyk, Z. Z., Burgess, N., Letcher, R., ... Lie, E. (2005). An assessment of the toxicological significance of anthropogenic contaminants in Canadian arctic wildlife. Science of the Total Environment, 351, 57-93. https://doi.org/10.1016/j.scitotenv. 2005.01.051

Gómez-Gutiérrez, A., Garnacho, E., Bayona, J. M., \& Albaigés, J. (2007). Assessment of the Mediterranean sediments contamination by persistent organic pollutants. Environmental Pollution, 148, 396-408. https://doi.org/10.1016/j.envpol.2006.12.012

Hall, A. J., Hugunin, K., Deaville, R., Law, R. J., Allchin, C. R., \& Jepson, P. D. (2006). The risk of infection from polychlorinated biphenyl exposure in the harbor porpoise (Phocoena phocoena): A case-control approach. Environmental Health Perspectives, 114, 704-711. https://doi.org/ 10.1289/ehp.8222

Hall, A. J., McConnell, B. J., \& Barker, R. J. (2001). Factors affecting firstyear survival in grey seals and their implications for life history strategy. Journal of Animal Ecology, 70, 138-149. https://doi.org/10.1111/ j.1365-2656.2001.00468.x

Hall, A. J., Thomas, G. O., \& McConnell, B. J. (2009). Exposure to persistent organic pollutants and first-year survival probability in gray seal pups. Environmental Science \& Technology, 43, 6364-6369. https://doi.org/ 10.1021/es9004398

Hammond, J. A., Hall, A. J., \& Dyrynda, E. A. (2005). Comparison of polychlorinated biphenyl $(\mathrm{CB})$ induced effects on innate immune functions in harbour and grey seals. Aquatic Toxicology, 74, 126-138. https://doi.org/10.1016/j.aquatox.2005.05.006

Helle, E., Olsson, M., \& Jensen, S. (1976a). DDT and PCB levels and reproduction in ringed from the Bothnian Bay. Ambio, 5, 188-189.
Helle, E., Olsson, M., \& Jensen, S. (1976b). PCB levels correlated with pathological changes in seal uteri. Ambio, 5, 261-263.

Houde, M., Wang, X., Ferguson, S. H., Gagnon, P., Brown, T. M., Tanabe, S., ... Muir, D. C. G. (2017). Spatial and temporal trends of alternative flame retardants and polybrominated diphenyl ethers in ringed seals (Phoca hispida) across the Canadian Arctic. Environmental Pollution, 223, 266-276. https://doi.org/10.1016/j.envpol.2017.01.023

Hoydal, K. S., Styrishave, B., Ciesielski, T. M., Letcher, R. J., Dam, M., \& Jenssen, B. M. (2017). Steroid hormones and persistent organic pollutants in plasma from Northeastern Atlantic pilot whales. Environmental Research, 159, 613-621. https://doi.org/10.1016/j.envres.2017. 09.003

Ikonomou, M. G., \& Addison, R. F. (2008). Polybrominated diphenyl ethers (BDEs) in seal populations from eastern and western Canada: An assessment of the processes and factors controlling BDE distribution in seals. Marine Environmental Research, 66, 225-230. https://doi.org/ 10.1016/j.marenvres.2008.02.004

Isobe, T., Ochi, Y., Ramu, K., Yamamoto, T., Tajima, Y., Yamada, T. K., ... Tanabe, S. (2009). Organohalogen contaminants in striped dolphins (Stenella coeruleoalba) from Japan: Present contamination status, body distribution and temporal trends (1978-2003). Marine Pollution Bulletin, 58, 396-401. https://doi.org/10.1016/j.marpolbul.2008.10.008

Jamieson, A. J., Malkocs, T., Piertney, S. B., Fujii, T., \& Zhang, Z. (2017). Bioaccumulation of persistent organic pollutants in the deepest ocean fauna. Nature Ecology \& Evolution, 1, 0051. https://doi.org/10.1038/ s41559-016-0051

Jepson, P. D., Deaville, R., Barber, J. L., Aguilar, À., Borrell, A., Murphy, S., ... Cunningham, A. A. (2016). CB pollution continues to impact populations of orcas and other dolphins in European waters. Scientific Reports, 6, 18573. https://doi.org/10.1038/srep18573

Jepson, P. D., \& Law, R. J. (2016). Persistent pollutants, persistent threats: Polychlorinated biphenyls remain a major threat to marine apex predators. Science, 352, 1388-1389. https://doi.org/10.1126/science. aaf9075

Johnson-Restrepo, B., Kannan, K., Rapaport, D. P., \& Rodan, B. D. (2005). Polybrominated diphenyl ethers and polychlorinated biphenyls in human adipose tissue from New York. Environmental Science \& Technology, 39, 5177-5182. https://doi.org/10.1021/es050399x

Jurado, E., Jaward, F. M., Lohmann, R., Jones, K. C., Simó, R., \& Dachs, J. (2004). Atmospheric dry deposition of persistent organic pollutants to the Atlantic and inferences for the global oceans. Environmental Science \& Technology, 38, 5505-5513. https://doi.org/10.1021/es049240v

Kalantzi, O. I., Hall, A. J., Thomas, G. O., \& Jones, K. C. (2005). Polybrominated diphenyl ethers and selected organochlorine chemicals in grey seals (Halichoerus grypus) in the North Sea. Chemosphere, 58, 345-354. https://doi.org/10.1016/j.chemosphere.2004.07.039

Kannan, K., Blankenship, A. L., Jones, P. D., \& Giesy, J. P. (2000). Toxicity reference values for the toxic effects of polychlorinated biphenyls to aquatic mammals. Human and Ecological Risk Assessment, 6, 181-201. https://doi.org/10.1080/10807030091124491

Law, R. J. (2014). An overview of time trends in organic contaminant concentrations in marine mammals: Going up or down? Marine Pollution Bulletin, 82, 7-10. https://doi.org/10.1016/j.marpolbul.2014.03.024

Law, R. J., Barry, J., Barber, J. L., Bersuder, P., Deaville, R., Reid, R. J., ... Smith, B. (2012). Contaminants in cetaceans from UK waters: Status as assessed within the Cetacean Strandings Investigation Programme from 1990 to 2008. Marine Pollution Bulletin, 64, 1485-1494. https:// doi.org/10.1016/j.marpolbul.2012.05.024

Lee, M. C., Han, J., Lee, S. H., Kim, D. H., Kang, H. M., Won, E. J., ... Lee, J. S. (2016). A brominated flame retardant 2, 2, 4, 4 tetrabrominated diphenyl ether (BDE-47) leads to lipogenesis in the copepod Tigriopus 
japonicus. Aquatic Toxicology, 178, 19-26. https://doi.org/10.1016/j. aquatox.2016.07.002

Louis, C., Covaci, A., Crocker, D. E., \& Debier, C. (2016). Lipophilicity of PCBs and fatty acids determines their mobilisation from blubber of weaned northern elephant seal pups. Science of the Total Environment, 541, 599-602. https://doi.org/10.1016/j.scitotenv.2015.09.094

Louis, C., Dirtu, A. C., Stas, M., Guiot, Y., Malarvannan, G., Das, K., ... Debier, C. (2014). Mobilisation of lipophilic pollutants from blubber in northern elephant seal pups (Mirounga angustirostris) during the postweaning fast. Environmental Research, 132, 438-448. https://doi.org/ 10.1016/j.envres.2014.04.016

Manzetti, S., Roos van der Spoel, E., \& van der Spoel, D. (2014). Chemical properties, environmental fate and degradation of seven classes of pollutants. Chemical Research in Toxicology, 27, 713-737. https://doi.org/ 10.1021/tx500014w

Méndez-Fernandez, P., Taniguchi, S., Santos, M. C., Cascão, I., Quérouil, S., Martin, V., ... Montone, R. C. (2018). Contamination status by persistent organic pollutants of the Atlantic spotted dolphin (Stenella frontalis) at the metapopulation level. Environmental Pollution, 236, 785-794. https://doi.org/10.1016/j.envpol.2018.02.009

Muir, D., \& Sverko, E. (2006). Analytical methods for CBs and organochlorine pesticides in environmental monitoring and surveillance: A critical appraisal. Analytical and Bioanalytical Chemistry, 386, 769-789. https://doi.org/10.1007/s00216-006-0765-y

Muir, D. C. G., Backus, S., Derocher, A. E., Dietz, R., Evans, T. J., Gabrielsen, G. W., ... Letcher, R. J. (2006). Brominated flame retardants in polar bears (Ursus maritimus) from Alaska, the Canadian Arctic, east Greenland and Svalbard. Environmental Science and Technology, 40, 449-455. https:// doi.org/10.1021/es051707u

Murphy, S., Pierce, G., Law, R., Bersuder, P., Jepson, P., Learmonth, J., ... Zegers, B. (2010). Assessing the effect of persistent organic pollutants on reproductive activity in common dolphins and harbour porpoises. Journal of Northwest Atlantic Fishery Science, 42, 153-173. https:// doi.org/10.2960/J.v42.m658

Noël, M., Barrett-Lennard, L., Guinet, C., Dangerfield, N., \& Ross, P. S. (2009). Persistent organic pollutants (POPs) in killer whales (Orcinus orca) from the Crozet Archipelago, southern Indian Ocean. Marine Environmental Research, 68, 196-202. https://doi.org/10.1016/j. marenvres.2009.06.009

Noël, M., Dangerfield, N., Jeffries, S., Lambourn, D., Lance, M., Helbing, C., ... Ross, P. S. (2017). Polychlorinated biphenyl related alterations of the expression of essential genes in harbour seals (Phoca vitulina) from coastal sites in Canada and the United States. Archives of Environmental Contamination and Toxicology, 73, 310-312. https://doi.org/10.1007/ s00244-016-0362-9

Ochiai, M., Nomiyama, K., Isobe, T., Yamada, T. K., Tajima, Y., Matsuda, A., ... Tanabe, S. (2017). Polybrominated diphenyl ethers (BDEs) and their hydroxylated and methoxylated analogues in the blood of harbor, Dall's and finless porpoises from the Japanese coastal waters. Marine Environmental Research, 128, 124-132. https://doi.org/10.1016/j.marenvres. 2016.11.004

Oftedal, O. T. (1993). The adaptation of milk secretion to the constraints of fasting in bears, seals, and baleen whales. Journal of Dairy Science, 76, 3234-3246. https://doi.org/10.3168/jds.S0022-0302(93)77660-2

Penin, I., Levin, M., Acevedo-Whitehouse, K., Jasperse, L., Gebhard, E., Gulland, F. M. D., \& De Guise, S. (2018). Effects of polychlorinated biphenyls (CB) on California sea lion (Zalophus californianus) lymphocyte functions upon in vitro exposure. Environmental Research, 167, 708-717. https://doi.org/10.1016/j.envres.2018.08.028

Pomeroy, P., Green, N., Hall, A., Walton, M., Jones, K., \& Harwood, J. (1996). Congener-specific exposure of grey seal (Halichoerus grypus) pups to chlorinated biphenyls during lactation. Canadian Journal of
Fisheries and Aquatic Sciences, 53, 1526-1534. https://doi.org/ 10.1139/f96-087

R Development Core Team. (2012). R: a language and environment for statistical computing. R Foundation for Statistics Computing, Vienna, Austria. http://www.R-project.org.

Ramu, K., Kajiwara, N., Tanabe, S., Lam, P. K. S., \& Jefferson, T. A. (2005). Polybrominated diphenyl ethers (BDEs) and organochlorines in small cetaceans from Hong Kong waters: Levels, profiles and distribution. Marine Pollution Bulletin, 51, 669-676. https://doi.org/10.1016/j. marpolbul.2005.02.041

Reijnders, P. J. (1986). Reproductive failure in common seals feeding on fish from polluted coastal waters. Nature, 324, 456-457. https://doi. org/10.1038/324456a0

Reilly, J. J. (1991). Adaptations to prolonged fasting in free-living weaned gray seal pups. American Journal of Physiology. Regulatory, Integrative and Comparative Physiology, 260, 267-272. https://doi.org/10.1152/ ajpregu.1991.260.2.R267

Ricking, M., \& Schwarzbauer, M. (2012). DDT isomers and metabolites in the environment, an overview. Environmental Chemistry Letters, 10, 317-323. https://doi.org/10.1007/s10311-012-0358-2

Rigét, F., Bignert, A., Braune, B., Dam, M., Dietz, R., Evans, M., ... Wilson, S. (2019). Temporal trends of persistent organic pollutants in Arctic marine and freshwater biota. The Science of the Total Environment, 649, 99-110. https://doi.org/10.1016/j.scitotenv.2018.08.268

Rigét, F., Vorkamp, K., Bossi, R., Sonne, C., Letcher, R. J., \& Dietz, R. (2016). Twenty years of monitoring of persistent organic pollutants in Greenland biota. A review. Environmental Pollution, 217, 114-123. https://doi.org/ 10.1016/j.envpol.2015.11.006

Rigét, F., Vorkamp, K., Dietz, R., \& Rastogi, S. C. (2006). Temporal trend studies on polybrominated diphenyl ethers (BDEs) and polychlorinated biphenyls (CBs) in ringed seals from East Greenland. Journal of Environmental Monitoring, 8, 1000-1005. https://doi.org/10.1039/B609522D

Robinson, K. J., Hall, A. J., Debier, C., Eppe, G., Thomé, J.-P., \& Bennett, K. A. (2018). Persistent organic pollutant burden, experimental POP exposure and tissue properties affect metabolic profiles of blubber from grey seal pups. Environmental Science and Technology, 52, 13523-13534. https://doi.org/10.1021/acs.est.8b04240

Roos, A. M., Bäcklin, B. M. V., Helander, B. O., Rigét, F. F., \& Eriksson, U. C. (2012). Improved reproductive success in otters (Lutra lutra), grey seals (Halichoerus grypus) and sea eagles (Haliaeetus albicilla) from Sweden in relation to concentrations of organochlorine contaminants. Environmental Pollution, 170, 268-275. https://doi.org/10.1016/j. envpol.2012.07.017

Rosen, D. A., \& Renouf, D. (1997). Seasonal changes in blubber distribution in Atlantic harbor seals: Indications of thermodynamic considerations. Marine Mammal Science, 13, 229-240. https://doi.org/10.1111/ j.1748-7692.1997.tb00630.x

Ross, P. S. (2006). Fireproof killer whales (Orcinus orca): Flame-retardant chemicals and the conservation imperative in the charismatic icon of British Columbia, Canada. Canadian Journal of Fisheries and Aquatic Sciences, 63, 224-234. https://doi.org/10.1139/f05-244

Ross, P. S., Ellis, G. M., Ikonomou, M. G., Barrett-Lennard, L. G., \& Addison, R. F. (2000). High CB concentrations in free-ranging Pacific killer whales, Orcinus orca: Effects of age, sex and dietary preference. Marine Pollution Bulletin, 40, 504-515. https://doi.org/10.1016/S0025326X(99)00233-7

Ross, P. S., Noël, M., Lambourn, D., Dangerfield, N., Calambokidis, J., \& Jeffries, S. (2013). Declining concentrations of persistent CBs, BDEs, PCDEs, and PCNs in harbor seals (Phoca vitulina) from the Salish Sea. Progress in Oceanography, 115, 160-170. https://doi.org/10.1016/j. pocean.2013.05.027 
Routti, H., Arukwe, A., Jenssen, B. M., Letcher, R. J., Nyman, M., Bäckman, C., \& Gabrielsen, G. W. (2010). Comparative endocrine disruptive effects of contaminants in ringed seals (Phoca hispida) from Svalbard and the Baltic Sea. Comparative Biochemistry and Physiology Part C: Toxicology \& Pharmacology, 152, 306-312. https://doi.org/10.1016/j. cbpc.2010.05.006

SANCO. (2014). Guidance document on analytical quality control and validation procedures for pesticide residues analysis in food and feed. SANCO/12571/2013 Supersedes SANCO/12495/2011. Official Journal of the European Communities, 2002, 48, 8-36.

Sanganyado, E., Rajput, I. R., \& Liu, W. (2018). Bioaccumulation of organic pollutants in Indo-Pacific humpback dolphin: A review on current knowledge and future prospects. Environmental Pollution, 237, 111-125. https://doi.org/10.1016/j.envpol.2018.01.055

Shaw, S. D., Brenner, D., Bourakovsky, A., Mahaffey, C. A., \& Perkins, C. R. (2005). Polychlorinated biphenyls and chlorinated pesticides in harbor seals (Phoca vitulina concolor) from the northwestern Atlantic coast. Marine Pollution Bulletin, 50, 1069-1084. https://doi.org/10.1016/j. marpolbul.2005.04.010

Shunthirasingham, C., Alexandrou, N., Brice, K. A., Dryfhout-Clark, H., Su, K., Shin, C., ... Hung, H. (2018). Temporal trends of halogenated flame retardants in the atmosphere of the Canadian Great Lakes Basin (2005-2014). Environmental Science: Processes \& Impacts, 20 469-479. https://doi.org/10.1039/c7em00549k

SMRU. (2017). Special committee on seals (SCOS); scientific advice on matters related to the Management of Seal Populations: 2017. Retrieved from SMRU Website: http://www.smru.st-andrews.ac.uk/ research-policy/scos/

Sonne, C., Letcher, R. J., Jenssen, B. M., Desforges, J.-P., Eulares, I., Anderson-Ranberg, E., ... Dietz, R. (2017). A veterinary perspective on One Health in the Arctic. Acta Veterinaria Scandinavica, 59, 84. https://doi.org/10.1186/s13028-017-0353-5

Sørmo, E. G., Larsen, H. J. R. S., Johansen, G. M., Skaare, J. U., \& Jenssen, B. R. M. (2009). Immunotoxicity of polychlorinated biphenyls (CB) in freeranging gray seal pups with special emphasis on dioxin-like congeners. Journal of Toxicology and Environmental Health, Part a, 72, 266-276. https://doi.org/10.1080/15287390802539251

Sørmo, E. G., Skaare, J. U., Jüssi, I., Jüssi, M., \& Jenssen, B. M. (2003). Polychlorinated biphenyls and organochlorine pesticides in Baltic and Atlantic gray seal (Halichoerus grypus) pups. Environmental Toxicology and Chemistry, 22, 2789-2799. https://doi.org/10.1897/02-556

Speranza, E. D., Colombo, M., Tatone, L. M., Cappelletti, N., Migoya, M. C., \& Colombo, J. C. (2016). Fatty acid alterations in the detritivorous Prochilodus lineatus promoted by opportunistic feeding on sewage discharges in the Río de la Plata estuary. Journal of Fish Biology, 89, 2024-2037. https://doi.org/10.1111/jfb.13104

Stapleton, H. M. (2006). Instrumental methods and challenges in quantifying polybrominated diphenyl ethers in environmental extracts: A review. Analytical and Bioanalytical Chemistry, 386, 807-817. https:// doi.org/10.1007/s00216-006-0400-y

Tanabe, S. (2002). Contamination and toxic effects of persistent endocrine disrupters in marine mammals and birds. Marine Pollution Bulletin, 45, 69-77. https://doi.org/10.1016/S0025-326X(02)00175-3

Tartu, S., Lille-Langøy, R., Størseth, T. R., Bourgeon, S., Brunsvik, A., Aars, J., ... Routti, H. (2017). Multiple-stressor effects in an apex predator: Combined influence of pollutants and sea ice decline on lipid metabolism in polar bears. Scientific Reports, 7, 16487. https://doi.org/ 10.1038/s41598-017-16820-5

United Nations Environment Programme (UNEP). (2001). Stockholm Convention on Persistent Organic Pollutants. Available at http://chm.pops.int/
Van Leeuwen, S. P. J., van Bavel, B., \& de Boer, J. (2013). First worldwide UNEP interlaboratory study on persistent organic pollutants (POPs), with data on polychlorinated biphenyls and organochlorine pesticides. Trends in Analytical Chemistry, 46, 110-117. https://doi.org/10.1016/ j.trac.2012.12.020

Vanden Berghe, M., Weijs, L., Habran, S., Das, K., Bugli, C., Rees, J. F., ... Debier, C. (2012). Selective transfer of persistent organic pollutants and their metabolites in grey seals during lactation. Environment International, 46, 6-15. https://doi.org/10.1016/j.envint.2012. 04.011

Villanger, G. D., Gabrielson, K. M., Kovacs, K. M., Lydersen, C., Lie, E., Karimi, M., ... Jenssen, B. M. (2013). Effects of complex organohalogen contaminant mixtures on thyroid homeostasis in hooded seal (Cystophora cristata) mother-pup pairs. Chemosphere, 92, 828-842. https://doi.org/10.1016/j.chemosphere.2013.04.036

Villanger, G. D., Lydersen, C., Kovacs, K. M., Lie, E., Skaare, J. U., \& Jenssen, B. M. (2011). Disruptive effects of persistent organohalogen contaminants on thyroid function in white whales (Delphinapterus leucas) from Svalbard. Science of the Total Environment, 409, 2511-2524. https://doi.org/10.1016/j.scitotenv.2011.03.014

Vorkamp, K., Rigét, F. F., Bossi, R., \& Dietz, R. (2011). Temporal trends of hexabromocyclododecane, polybrominated diphenyl ethers and polychlorinated biphenyls in ringed seals from East Greenland. Environmental Science \& Technology, 45, 1243-1249. https://doi.org/10.1021/ es102755x

Vorkamp, K., Rigét, F. F., Glasius, M., Muir, D. C. G., \& Dietz, R. (2008). Levels and trends of persistent organic pollutants in ringed seals (Phoca hispida) from Central West Greenland, with particular focus on polybrominated diphenyl ethers (PBDEs). Environment International, 34, 499-508. https://doi.org/10.1016/j.envint.2007.11.004

Wang, P., Zhang, Q., Wang, Y., Wang, T., Li, X., Ding, L., \& Jiang, J. (2010). Evaluation of Soxhlet extraction, accelerated solvent extraction and microwave-assisted extraction for the determination of polychlorinated biphenyls and polybrominated diphenyl ethers in soil and fish samples. Analytica Chimica Acta, 663, 43-48. https://doi.org/ 10.1016/j.aca.2010.01.035

Weijs, L., Das, K., Siebert, U., van Elk, N., Jauniaux, T., Neels, H., ... Covaci, A. (2009). Concentrations of chlorinated and brominated contaminants and their metabolites in serum of harbour seals and harbour porpoises. Environment International, 35, 842-850. https://doi.org/10.1016/j. envint.2009.02.001

Weijs, L., Dirtu, A. C., Das, K., Gheorghe, A., Reijnders, P. J., Neels, H., ... Covaci, A. (2009). Inter-species differences for polychlorinated biphenyls and polybrominated diphenyl ethers in marine top predators from the Southern North Sea: Part 1. Accumulation patterns in harbour seals and harbour porpoises. Environmental Pollution, 157, 437-444. https://doi.org/10.1016/j.envpol.2008.09.024

Yadetie, F., Oveland, E., Døskeland, A., Berven, F., Goksøyr, A., \& Karlsen, O. A. (2017). Quantitative proteomics analysis reveals perturbation of lipid metabolic pathways in the liver of Atlantic cod (Gadus morhua) treated with CB 153. Aquatic Toxicology, 185, 19-28. https://doi.org/ 10.1016/j.aquatox.2017.01.014

How to cite this article: Robinson KJ, Hall AJ, Scholl G, et al. Investigating decadal changes in persistent organic pollutants in Scottish grey seal pups. Aquatic Conserv: Mar Freshw Ecosyst. 2019;29(S1):86-100. https://doi.org/10.1002/aqc.3137 